\title{
Diversity of AMF associated with Ammophila arenaria ssp. arundinacea in Portuguese sand dunes
}

\author{
Susana Rodríguez-Echeverría $\cdot$ Helena Freitas
}

Received: 8 March 2006/Accepted: 13 July 2006 / Published online: 17 October 2006

(C) Springer-Verlag 2006

\begin{abstract}
Dune vegetation is essential for the formation and preservation of sand dunes and the protection of the coast line. Coastal sand dunes are harsh environments where arbuscular mycorrhizal fungi (AMF) play an important role in promoting plant establishment and growth. We present a study of the diversity of AMF associated with A. arenaria ssp. arundinacea in two locations of the Portuguese coast under a Mediterranean climate. These two locations were selected to compare a well-preserved dune system from a protected area with a degraded dune system from a public beach. AMF diversity was assessed mainly by cloning and sequencing of a fragment of the ribosomal SSU using the primer NS31 and AM1. Most of the 89 AMF clones obtained from the rhizosphere and roots of $A$. arenaria belonged to the genus Glomus, the largest clade within the Glomeromycota. Higher AMF diversity was found in the least disturbed site, in which spores of Scutellospora persica, Glomus constrictum and Glomus globiferum were found in the rhizosphere of $A$. arenaria.
\end{abstract}

Keywords Coast · Marram grass · Mediterranean climate . Molecular diversity Polymerase chain reaction

\section{Introduction}

Vegetation plays a key role in the stabilization and preservation of coastal sand dunes, which are among the most threatened habitats in areas under Mediterranean

S. Rodríguez-Echeverría $(\bowtie) \cdot H$. Freitas

IMAR, Department of Botany, University of Coimbra,

3000, Coimbra, Portugal

e-mail: susanare@ci.uc.pt climate. Nonetheless, the establishment and survival of pioneer plants in sand dunes is hampered by harsh abiotic conditions (low soil fertility, strong wind, sand accretion). Arbuscular mycorrhizal fungi (AMF) are instrumental in promoting plant establishment and growth in these environments by enhancing plant nutrient and water uptake, protecting plants from root herbivores and pathogens and improving soil structure (Allen 1996; Azcón-Aguilar and Barea 1996; de la Peña et al. 2006; Koske 1975; Koske and Polson 1984).

Ammophila arenaria (L.) Link (marram grass) is the most important sand-fixing species in the European coast. This is a perennial, rhizomatous grass that occurs in coastal foredunes of Europe and North Africa (Tutin et al. 1980), and needs regular sand-burial to grow vigorously. Thus, A. arenaria is the dominant species at the seaward slope and top of foredunes where sand accretion is intense (Greig-Smith 1961; Huiskes 1979). Two subspecies of A. arenaria grow naturally in Europe: A. arenaria ssp. arenaria in the northern and western coast down to the north coast of the Iberian Peninsula and A. arenaria ssp. arundinacea in areas under Mediterranean climate (Tutin et al. 1980). Previous studies have shown typical structures of AMF (coils, arbuscules, vesicles and hyphae) inside the roots of $A$. arenaria as well as spores and mycelia in its rhizosphere (Giovannetti and Nicolson 1983; Kowalchuk et al. 2002; Maremmani et al. 2003). The growing evidence of the multifunctionality and importance of AMF diversity for ecosystem functioning have led to a great effort to identify the species that colonize plants in natural systems. Several Glomus, Scutellospora and Acaulospora species have been found associated with $A$. arenaria ssp. arenaria in European coastal dunes (Blaszkowski 1994; Blaszkowski and Tadych 1997; Blaszkowski et al. 2001; Kowalchuk et al. 2002). Spore morphology has been used as the main tool 
to identify AMF species but in recent years molecular techniques have also been successfully applied in species description (Kramadibrata et al. 2000; Redecker et al. 2000) and in the study of AMF diversity in natural systems (Douhan et al. 2005; Ferrol et al. 2004; Husband et al. 2002; Kowalchuk et al. 2002; Öpik et al. 2003; Rosendahl and Stukenbrock 2004; van Tuinen et al. 1998; Vandenkoornhuyse et al. 2003). An analysis based solely on spore counting and identification is problematic because sporulation depends on the biology of particular AMF species and their interaction with environmental conditions. Also, an accurate identification of spores extracted from field samples may be hampered because spores may be unrecognisable due to degradation. One of the main advantages of molecular techniques is the possibility of direct analysis of AMF in planta. Molecular techniques have also shown an unexpected high genetic diversity of AMF, although the true extent of variability within species or individuals remains obscure (Sanders 2004).

About $75 \%$ of the Mediterranean coastal sand dunes have been destroyed or severely degraded in the last 100 years as a consequence of increased human pressure (Carter 1988). When restoration programs have been implemented, they have invariably used $A$. arenaria to create and stabilize the primary dunes. Although AMF are assumed to be important in the success of restoration projects in coastal dunes, little is known about the diversity of these organisms associated with $A$. arenaria in the Mediterranean coast (Giovannetti 1985; Giovannetti and Nicolson 1983). We present a study of the diversity of AMF associated with A. arenaria ssp. arundinacea in two Portuguese coastal locations under Mediterranean climatic conditions. These two locations were selected to compare a well-preserved dune system from a protected area with a degraded dune system from a public beach.

The diversity of AMF in planta was studied with nestedPCR and sequencing targeting the 18S-rRNA. Additional sequences were obtained from superficially healthy spores extracted both from field samples and pot cultures. Spores extracted from field samples and pot cultures were identified to species where possible.

\section{Materials and methods}

\section{Sampling}

Monospecific stands of Ammophila arenaria (L.) Link ssp. arundinacea were selected in the foredunes from two Portuguese coastal locations, the Natural Reserve of São Jacinto (N40 $41^{\prime}$ W08 $\left.44^{\prime}\right)$ and Comporta (N38 $23^{\circ}$, W08 $\left.48^{\prime}\right)$. The dune system in the Natural Reserve of São Jacinto is well-preserved with a healthy vigorous population of
A. arenaria dominant in the foredunes. Comporta is a public beach where the vegetation of the foredunes is heavily disturbed. Plants of $A$. arenaria in this site are fewer and smaller than in São Jacinto.

Roots and soil from the rhizosphere were collected from four different foredunes separated by $50 \mathrm{~m}$ following a line parallel to the coastline in both locations. Samples were collected in July 2003, November 2003 and April 2004 from individual plants. In each sampling, the dune was excavated to expose the roots of $A$. arenaria and $500 \mathrm{~g}$ of soil and roots were collected from that point.

Extraction and identification of spores

The rhizosphere soil collected in July and November 2003 was used to set up trap cultures using Zea mays (L.) as host plant. After 3 months, pots were checked for spore production and spores with different morphology were separated to attempt establishment of single-species cultures with one to five spores of the same morphology. Pure cultures were harvested and checked for mycorrhizal colonisation and spore production 3 months after the establishment. Only three cultures were successful, one started with spores originally from São Jacinto and the other two from Comporta. Healthy spores from each culture were selected under a dissecting microscope to be used for DNA extraction. Permanent slides were also mounted with PVLG (polyvinyl alcohol, lactic acid, glycerine) and PVLG + Melzer's reagent (1:1). Dr. Chris Walker examined the spores for species determination using both fresh spores from the trap cultures and the collection of permanent slides.

DNA extraction from spores and roots

Individual spores that were apparently healthy when examined through a dissecting microscope were selected from field samples and trap cultures, sonicated and rinsed with autoclaved water three times, washed with $2 \%$ Chloramin- $\mathrm{T}$ for $15 \mathrm{~min}$ and rinsed again with autoclaved water. A single spore was crushed in $40 \mu \mathrm{l}$ of TE buffer $10 \mathrm{mM}(\mathrm{pH} 8.0)$ in a $1.5-\mathrm{ml}$ tube using a micropestle. Afterwards, $10 \mu \mathrm{l}$ of Chelex $20 \%$ was added to the solution, tubes were incubated for $10 \mathrm{~min}$ at $95^{\circ} \mathrm{C}$ and then left to cool down on ice. Finally, the samples were centrifuged at $10,000 \times g$ for $1 \mathrm{~min}$ and the supernatant, containing the DNA, was transferred to a new tube (Kowalchuk et al. 2002).

Roots collected from A. arenaria were stained with ink (Blue Quink, Parker) (Walker 2005). Roots were cleared in $2.5 \%(\mathrm{w} / \mathrm{v}) \mathrm{KOH}$ for $1 \mathrm{~h}$ at $90^{\circ} \mathrm{C}$, rinsed with tap water and immersed in $1 \%(\mathrm{v} / \mathrm{v}) \mathrm{HCl}$ overnight. The following day, roots were stained with $1 \%(\mathrm{v} / \mathrm{v})$ ink in $1 \% \mathrm{HCl}$ for $30 \mathrm{~min}$ 
at $60^{\circ} \mathrm{C}$. AMF colonization was examined under a compound microscope. Root colonization was around $40 \%$ in all samples. DNA was extracted from $1-\mathrm{cm}$ root fragments using the Qiagen DNAeasy Plant Minikit (Qiagen). All DNA samples were stored at $-20^{\circ} \mathrm{C}$.

\section{DNA amplification}

A nested-PCR was used to selectively amplify fungal DNA from the extracts. The first PCR used the forward primer NS1 in combination with the reverse primer ITS4, covering the region from the beginning of the $18 \mathrm{~S}$ rRNA gene through the $5^{\prime}$ end of the $25 \mathrm{~S}$ rRNA gene (De Souza et al. 2004; White et al. 1990). PCRs were performed in a final volume of $20 \mu \mathrm{l}$ using $200 \mu \mathrm{M}$ of each dNTP (Amersham), $1.5 \mathrm{M} \mathrm{MgCl}_{2}, 0.4 \mu \mathrm{M}$ of each primer, and $1 \mathrm{U}$ of the Taq DNApolymerase (Amersham Pharmacia). $5 \mu$ were used from the DNA extracts of spores, and $1 \mu$ of a 1:10 dilution of the DNA extracts from the roots. The PCR program was: $94^{\circ} \mathrm{C}$ for $4 \mathrm{~min} ; 30$ cycles of $\left(94^{\circ} \mathrm{C}, 30 \mathrm{~s} ; 55^{\circ}\right.$ C, $40 \mathrm{~s} ; 68^{\circ} \mathrm{C} 2 \mathrm{~min}+5 \mathrm{~s}$ per cycle); and $68^{\circ} \mathrm{C}$ for $7 \mathrm{~min}$. All reactions were carried out in a GeneAmp PCR 9700 (Perkin Elmer). The products of this first PCR were diluted $(250 \mu \mathrm{l}$ of sterile water were added when the PCR product was visible in an agarose gel and $150 \mu$ lo those reactions without product) and used in the second PCR with the primers NS31 (Simon et al. 1992) and AM1 (Helgason et al. 1998) targeted at the region V3-V4 of the 18S rRNA gene and designed to specifically amplified AMF sequences. The reactions were performed in a final volume of $25 \mu \mathrm{l}$ using $1 \mu \mathrm{l}$ of DNA template and the same conditions as detailed above with the following program: $94^{\circ} \mathrm{C}$ for $2 \mathrm{~min} ; 35$ cycles of $\left(92^{\circ} \mathrm{C}, 30 \mathrm{~s} ; 61^{\circ} \mathrm{C}, 60 \mathrm{~s} ; 68^{\circ} \mathrm{C} 50 \mathrm{~s}+1 \mathrm{~s}\right.$ per cycle); and $68^{\circ} \mathrm{C}$ for $5 \mathrm{~min}$. All reactions were carried out in a GeneAmp PCR 9700 (Perkin Elmer). The products from the second PCR were examined by standard 1\% (w/v) agarose gel electrophoresis with ethidium bromide staining, to confirm product integrity and estimate yield.

DNA purification, cloning and sequencing

The products from the second PCR were purified using the QiaQuick PCR purification kit (Qiagen, Hilden, Germany) with a final elution volume of $30 \mu \mathrm{l}$. Cloning of the purified products was done using the pGEM-T Easy Vector System from Promega (Madison, WI, USA) according to the manufacturer's protocol. Three colonies from each cloning reaction were grown overnight at $37^{\circ} \mathrm{C}$ with shaking at 200 r.p.m. in $3 \mathrm{ml}$ Luria-Bertani medium supplemented with $100 \mathrm{mg} / \mathrm{ml}$ ampicillin. Plasmids were purified using the Rapid Plasmid DNA daily mini-prep kit (Bioron $\mathrm{GmbH}$, Ludwigshafen, Germany) following the manufacturer's protocol. Positive clones were sequenced, only in one direction, using ABI PRISM Dye Terminator Cycle Sequence Ready Reaction Kit according to manufacturer's instructions (Perkin Elmer, CA, USA).

All sequences were compared to sequences in Internet databases using BLAST to check for similarities with previously described species (Altschul et al. 1997) and were checked for putative chimeric sequences using the online chimera checker program at the Ribosomal Database Project (http://rdp8.cme.msu.edu/cgis/chimera.cgi? $\mathrm{su}=\mathrm{SSU})$. The sequences obtained in this study have been deposited in the GenBank (for accession numbers see Table 1). The closest BLAST hits from described species, the sequences used by Schwarzott et al. (2001), and two outgroup taxa (Endogone pisiformis Link (X58724), Mortierella polycephala Coem. (X89436)) were acquired from GenBank/EMBL databases and used in the phylogenetic analysis. Sequences were aligned using BioEdit (Hall 1999). Consensus trees were constructed from a 1,000-fold bootstrapped neighbour-joining (NJ) analyses based on Kimura's two-parameter distances (Kimura 1980) using PHYLIP 3.5 (Felsenstein 1993). Trees were visualized with TreeView 1.6.6 (Page 2001).

\section{Results}

Spores from Scutellospora and Glomus species were found in the rhizosphere and inside fine roots collected under plants of $A$. arenaria in São Jacinto and Comporta. The determination of species was done for the three most abundant morphological types found in São Jacinto. These species, extracted from both field samples and trap cultures, were identified as Scutellospora persica, Glomus constrictum and Glomus globiferum. Pure cultures starting from one to five spores from trap cultures were attempted for those species but successful cultures were only obtained for S. persica. No species were identified from spores extracted from the field samples from Comporta, but two successful pure cultures were obtained which are currently being examined by Dr. Chris Walker to achieve species identification. One of those cultures contained dark glomoid spores of about 100-150 $\mu \mathrm{m}$ diameter and thick external wall component. The second pure culture from Comporta contained yellow glomoid spores grouped in clusters and sporulating inside moribund roots.

Obtained from the $A$. arenaria roots and spores collected in Comporta and São Jacinto were 89 different fungal sequences (Table 2). A first analysis divided the sequences into two main groups (Fig. 1). BLAST analysis showed that the biggest cluster contained 69 sequences with high homology to members of the Glomeromycota. The second group contained 20 sequences that were more similar to organisms in either the Ascomycota or the Basidiomycota. 
Table 1 Correspondence of GenBank accession numbers with the clone names used in the manuscript

\begin{tabular}{|c|c|c|c|c|}
\hline Accession \# GenBank & Clone & Sample & Site & Fungi \\
\hline AY882582 & SJsp11 & Spore & São Jacinto & Glomeromycota \\
\hline AY882583 & SJsp21 & Spore & São Jacinto & Glomeromycota \\
\hline AY882584 & SJsp77 & Spore & São Jacinto & Glomeromycota \\
\hline DQ357072 & Csp29 & Spore & Comporta & Glomeromycota \\
\hline DQ357073 & Csp30 & Spore & Comporta & Glomeromycota \\
\hline DQ357074 & Csp81 & Spore & Comporta & Glomeromycota \\
\hline DQ357075 & Csp82 & Spore & Comporta & Glomeromycota \\
\hline DQ357076 & Csp84 & Spore & Comporta & Glomeromycota \\
\hline DQ357077 & Csp85 & Spore & Comporta & Glomeromycota \\
\hline DQ357079 & SJsp79 & Spore & São Jacinto & Glomeromycota \\
\hline DQ357080 & CCons 2 & Root & Comporta & Glomeromycota \\
\hline DQ357081 & $\mathrm{C} 207$ & Root & Comporta & Glomeromycota \\
\hline DQ357082 & $\mathrm{C} 210$ & Root & Comporta & Glomeromycota \\
\hline DQ357083 & $\mathrm{C} 22$ & Root & Comporta & Glomeromycota \\
\hline DQ357087 & $\mathrm{C} 311$ & Root & Comporta & Glomeromycota \\
\hline DQ357088 & $\mathrm{C} 312$ & Root & Comporta & Glomeromycota \\
\hline DQ357089 & $\mathrm{C} 313$ & Root & Comporta & Glomeromycota \\
\hline DQ357090 & $\mathrm{C} 415$ & Root & Comporta & Glomeromycota \\
\hline DQ357091 & C51 & Root & Comporta & Glomeromycota \\
\hline DQ357092 & C518 & Root & Comporta & Glomeromycota \\
\hline DQ357093 & $\mathrm{C} 520$ & Root & Comporta & Glomeromycota \\
\hline DQ357094 & C521 & Root & Comporta & Glomeromycota \\
\hline DQ357095 & $\mathrm{C} 54$ & Root & Comporta & Glomeromycota \\
\hline DQ357101 & $\mathrm{Ca} 21$ & Root & Comporta & Glomeromycota \\
\hline DQ357102 & $\mathrm{Ca} 211$ & Root & Comporta & Glomeromycota \\
\hline DQ357103 & $\mathrm{Ca} 22$ & Root & Comporta & Glomeromycota \\
\hline DQ357104 & $\mathrm{Ca} 25$ & Root & Comporta & Glomeromycota \\
\hline DQ357105 & $\mathrm{Ca} 26$ & Root & Comporta & Glomeromycota \\
\hline DQ357107 & $\mathrm{Ca} 41$ & Root & Comporta & Glomeromycota \\
\hline DQ357108 & $\mathrm{Ca} 410$ & Root & Comporta & Glomeromycota \\
\hline DQ357109 & $\mathrm{Ca} 411$ & Root & Comporta & Glomeromycota \\
\hline DQ357110 & $\mathrm{Ca} 412$ & Root & Comporta & Glomeromycota \\
\hline DQ357111 & $\mathrm{Ca} 413$ & Root & Comporta & Glomeromycota \\
\hline DQ357112 & $\mathrm{Ca} 414$ & Root & Comporta & Glomeromycota \\
\hline DQ357113 & $\mathrm{Ca} 416$ & Root & Comporta & Glomeromycota \\
\hline DQ357114 & $\mathrm{Ca} 417$ & Root & Comporta & Glomeromycota \\
\hline DQ357115 & $\mathrm{Ca} 42$ & Root & Comporta & Glomeromycota \\
\hline DQ357116 & $\mathrm{Ca} 43$ & Root & Comporta & Glomeromycota \\
\hline DQ357117 & $\mathrm{Ca} 45$ & Root & Comporta & Glomeromycota \\
\hline DQ357118 & $\mathrm{Ca} 47$ & Root & Comporta & Glomeromycota \\
\hline DQ357119 & $\mathrm{Ca} 48$ & Root & Comporta & Glomeromycota \\
\hline DQ357120 & $\mathrm{Ca} 49$ & Root & Comporta & Glomeromycota \\
\hline DQ357121 & ConsCa1 & Root & Comporta & Glomeromycota \\
\hline DQ357122 & $\mathrm{C} 25$ & Root & Comporta & Ascomycota \\
\hline DQ357123 & $\mathrm{C} 27$ & Root & Comporta & Ascomycota \\
\hline DQ357124 & $\mathrm{C} 28$ & Root & Comporta & Ascomycota \\
\hline DQ357125 & C61 & Root & Comporta & Basidiomycota \\
\hline DQ357126 & C62 & Root & Comporta & Basidiomycota \\
\hline DQ357127 & C65 & Root & Comporta & Basidiomycota \\
\hline DQ357128 & $\mathrm{C} 81$ & Root & Comporta & Ascomycota \\
\hline DQ357129 & $\mathrm{C} 83$ & Root & Comporta & Ascomycota \\
\hline DQ357130 & $\mathrm{Ca} 29$ & Root & Comporta & Ascomycota \\
\hline DQ357131 & SJ1 & Root & São Jacinto & Ascomycota \\
\hline DQ357132 & SJ13 & Root & São Jacinto & Ascomycota \\
\hline DQ357133 & SJ14 & Root & São Jacinto & Ascomycota \\
\hline DQ357134 & SJ15 & Root & São Jacinto & Ascomycota \\
\hline
\end{tabular}


Table 1 (continued)

\begin{tabular}{|c|c|c|c|c|}
\hline Accession \# GenBank & Clone & Sample & Site & Fungi \\
\hline DQ357135 & SJ16 & Root & São Jacinto & Ascomycota \\
\hline DQ357136 & $\mathrm{SJ} 2$ & Root & São Jacinto & Ascomycota \\
\hline DQ357137 & SJ3 & Root & São Jacinto & Ascomycota \\
\hline DQ357138 & SJ32 & Root & São Jacinto & Ascomycota \\
\hline DQ357139 & SJ33 & Root & São Jacinto & Ascomycota \\
\hline DQ357140 & SJ4 & Root & São Jacinto & Ascomycota \\
\hline DQ357141 & SJcons & Root & São Jacinto & Ascomycota \\
\hline DQ357152 & SJ41 & Root & São Jacinto & Glomeromycota \\
\hline DQ357153 & SJ42 & Root & São Jacinto & Glomeromycota \\
\hline DQ357154 & SJ43 & Root & São Jacinto & Glomeromycota \\
\hline DQ357155 & SJ44 & Root & São Jacinto & Glomeromycota \\
\hline DQ357156 & SJ441 & Root & São Jacinto & Glomeromycota \\
\hline DQ357157 & SJ442 & Root & São Jacinto & Glomeromycota \\
\hline DQ357158 & SJ45 & Root & São Jacinto & Glomeromycota \\
\hline DQ357159 & SJ649 & Root & São Jacinto & Glomeromycota \\
\hline DQ357160 & SJa11 & Root & São Jacinto & Glomeromycota \\
\hline DQ357161 & SJa110 & Root & São Jacinto & Glomeromycota \\
\hline DQ357162 & SJa111 & Root & São Jacinto & Glomeromycota \\
\hline DQ357163 & SJa112 & Root & São Jacinto & Glomeromycota \\
\hline DQ357164 & SJa113 & Root & São Jacinto & Glomeromycota \\
\hline DQ357165 & SJa12 & Root & São Jacinto & Glomeromycota \\
\hline DQ357166 & SJa15 & Root & São Jacinto & Glomeromycota \\
\hline DQ357167 & SJa17 & Root & São Jacinto & Glomeromycota \\
\hline DQ357168 & Sja19 & Root & São Jacinto & Glomeromycota \\
\hline DQ357169 & SJa33 & Root & São Jacinto & Glomeromycota \\
\hline DQ357170 & SJa34 & Root & São Jacinto & Glomeromycota \\
\hline DQ357171 & SJa37 & Root & São Jacinto & Glomeromycota \\
\hline DQ357172 & SJa39 & Root & São Jacinto & Glomeromycota \\
\hline DQ357173 & SJacon & Root & São Jacinto & Glomeromycota \\
\hline DQ357174 & SJaCons1 & Root & São Jacinto & Glomeromycota \\
\hline DQ357175 & SJaCons2 & Root & São Jacinto & Glomeromycota \\
\hline DQ380231 & Sjsp711 & Spore & São Jacinto & Glomeromycota \\
\hline DQ380232 & SJsp71 & Spore & São Jacinto & Glomeromycota \\
\hline
\end{tabular}

Origin of each sequence and fungal group to which they belong (based on BLAST analysis)

Most of the sequences with similarity to members of the phylum Glomeromycota fell into the order Glomerales (Fig. 2). Only four sequences obtained from field samples from São Jacinto belonged to the order Diversisporales. Three of those sequences (SJsp711, SJsp71, SJsp79) had a high similarity with sequences from $D$. spurcum and a species morphologically similar to G. etunicatum obtained from GenBank and clustered in the family Diversisporaceae. The spores from which these sequences originated were found occupying $A$. arenaria roots (SJsp71) and inside a dead $S$. persica spore (SJsp79, SJsp711). The fourth sequence was obtained from one spore determined to be of S. persica (SJsp77) and clustered with other Scutellospora sequences obtained from GenBank and within the family Gigasporaceae. Sequencing was also done from spores extracted from the single-species cultures of $S$. persica and the two Glomus types from Comporta. Two similar sequences were obtained from spores of

Table 2 Number of sequences obtained from A. arenaria roots and AMF spores from each sampling site

\begin{tabular}{lllll}
\hline Site & DNA from & Glomeromycota sequences & Ascomycota sequences & Basiodiomycota sequences \\
\hline São Jacinto & Root & 24 & 11 & 0 \\
& Spore & 6 & 0 & 0 \\
Comporta & Root & 33 & 6 & 3 \\
& Spore & 6 & 0 & 0 \\
Total & & 69 & 17 & 3 \\
\hline
\end{tabular}




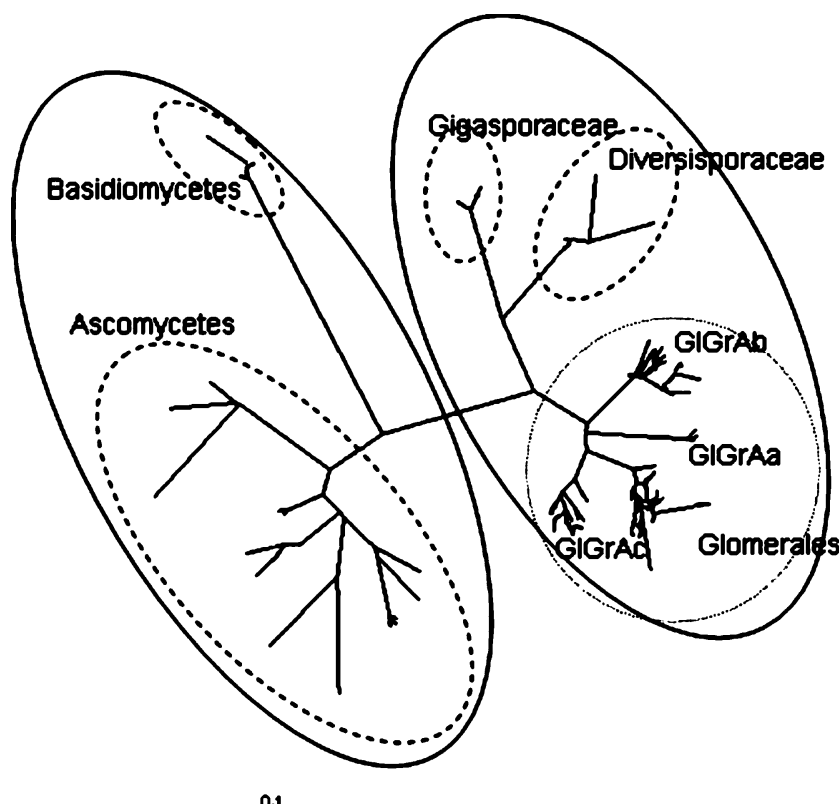

Fig. 1 Unrooted tree based on Kimura's two parameter distances inferred from partial SSU rDNA fungal sequences from the clones obtained from $A$. arenaria roots and AMF spores. Taxonomic classification follows Schwarzott et al. (2001). GlGrAa, Ab and Ac are the subclades defined within the clade GlGrA (Glomus Group A). All sequences obtained in this study belonging to the genus Glomus clustered into the clade GlGrA

S. persica (SJsp11, SJsp21) and clustered within the Gigasporaceae. The three sequences (SJsp77, SJsp11, SJsp21) obtained from spores of $S$. persica were grouped together with high bootstrap values. The sequences obtained from the spores from Comporta (Csp81, Csp82, Csp84, Csp85 for the first morphotype, and Csp29, Csp30 for the second one) clustered in two different groups within the Glomeraceae (Glomus group A).

The clones of Glomeromycota fungi obtained from the root samples were grouped in four clusters within the Glomeraceae family. A BLAST search revealed high levels of homology between some of the sequences obtained in this study and Glomus sequences obtained in studies from grasslands (Wirsel 2004), sand dunes (Kowalchuk et al. 2002), and with species identified as $G$. intraradices, G. fasciculatum, G. hoi and G. constrictum. Five sequences obtained from root samples clustered with $G$. constrictum (AJ506090), confirming the presence inside A. arenaria roots of this species identified from spores. Several sequences obtained from the roots from Comporta clustered with the sequences Csp81-84 from spores, also indicating the presence inside the roots of those AMF species detected in the rhizosphere.

Three non-glomeromycotan sequences from samples from Comporta showed a high similarity with the basidiomycotan yeasts Dioszegia hungarica and Bullera armeniaca (Fig. 3). The remaining 17 non-glomeromycotan sequences from Comporta and São Jacinto corresponded to ascomycotous fungi. Four clusters were obtained in the phylogenetic analysis using our sequences and those of the closest BLAST hits (Fig. 3). Out of 11 sequences obtained from São Jacinto, 9 displayed a high similarity and clustered together with plant pathogens such as Fusarium cerealis, F. culmorum and Verticillum longisporum and with the nematophagous fungi Plectosphaerella cucumerina. The other two sequences from São Jacinto clustered with one sequence from Comporta and the opportunistic human pathogens Cladophialophora carrionii, Phialophora verrucosa and Cyphelophora laciniata. Two sequences from Comporta clustered with Geomyces pannorum, a common soil saprophytic fungus that is also an opportunistic human pathogen, and the grass pathogen Blumera graminis. The fourth group contained three sequences from Comporta, the cereal pathogens Microdochium nivale and Monographella nivalis, and, with lower bootstrap values, the saprophytic fungi Hyponectria buxi and Pestalotiopsis sp.

\section{Discussion}

The AM1-NS31 primer pair has been extensively used to selectively amplify the SSU rDNA from AMF (Helgason et al. 1998; Kowalchuk et al. 2002). However, our results agree with recent studies that have found low stringency for the pair AM1-NS31 and amplification of DNA from Glomeromycota, Ascomycota and Basidiomycota fungi (Douhan et al. 2005; Ma et al. 2005). Although AM1 was first defined as specific for AMF, the sequence of the AM1 region is as variable within the Glomeromycota members as between those members of the Ascomycota and Basidiomycota (Douhan et al. 2005). The amplification of DNA from ascomycetes and basidiomycetes shows that care should be taken when using this primer combination for the analysis of AMF communities of field samples, especially if sequencing is not involved in the study.

All the AMF sequences obtained from the roots of A. arenaria fit into the genus Glomus, the largest within the phylum Glomeromycota (Schüßler et al. 2001), and within the group GlGrA (Schwarzott et al. 2001). Only sequences from São Jacinto grouped within the cluster GlGrAa (Schwarzott et al. 2001), together with G. mosseae, G. coronatum, G. geosporum and G. constrictum. Five clones from São Jacinto and nine clones from Comporta

Fig. 2 Neighbour joining analysis based on Kimura's two parameter distances inferred from partial SSU rDNA sequences from AMF. The sequences obtained in this study are marked with black (Comporta) and grey (São Jacinto) dots. Taxonomic classification follows Schwarzott et al. (2001). Within the Glomeraceae, only clades GlGrA and GlGrB are represented here. GlGrAa, $\mathrm{Ab}$ and $\mathrm{Ac}$ are the subclades defined within the clade GlGrA (Glomus Group A). Bootstrap values are based on 1,000 replicates, percentage values are shown 
M. polycephalla

A. fumigatus

G. sinuosum

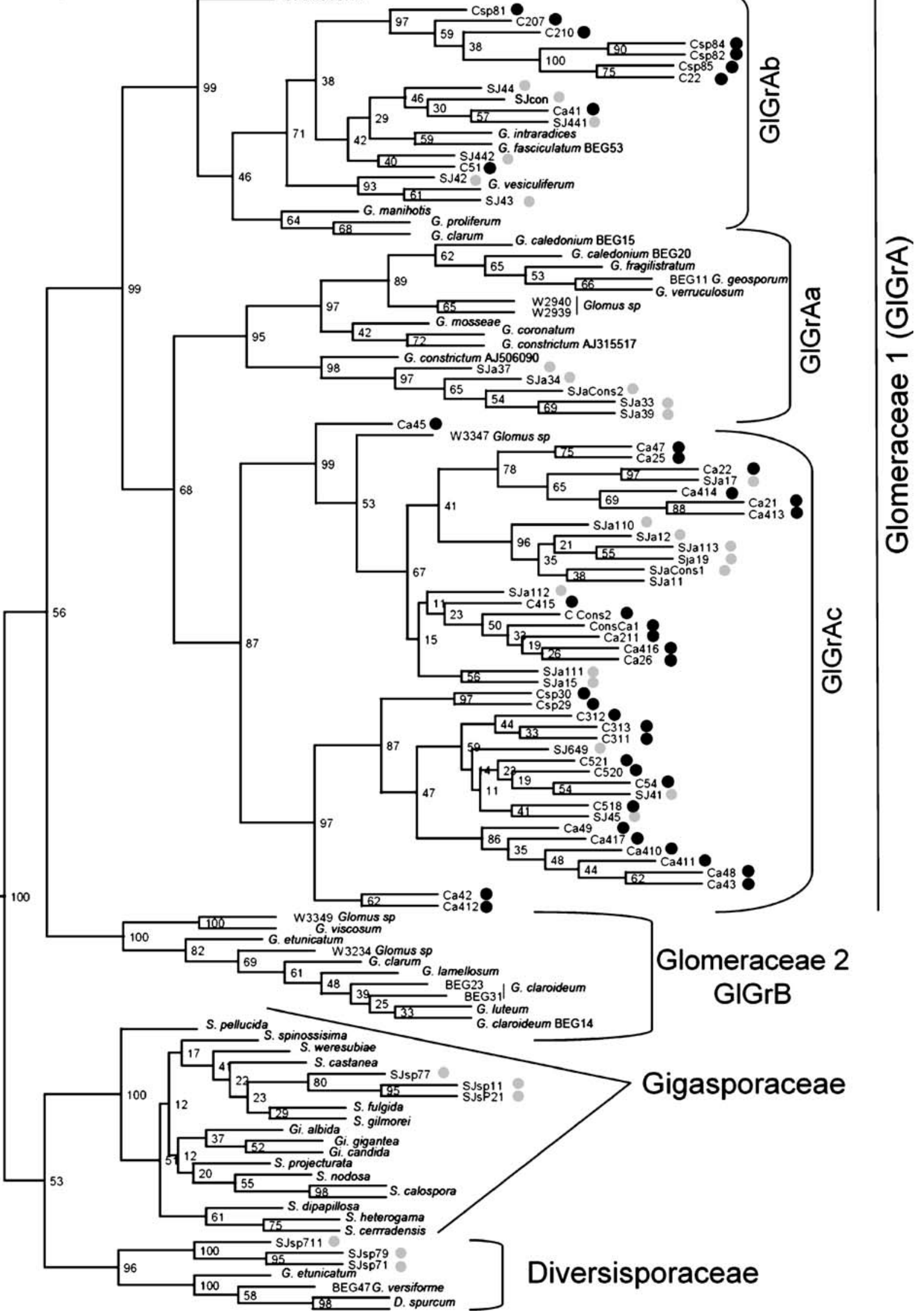


Fig. 3 Neighbour joining analysis based on Kimura's two parameter distances inferred from partial SSU rDNA sequences from the non-AMF sequences found in this study and sequences from Ascomycota and Basidiomycota members obtained from the GenBank The sequences obtained in this study are marked with black (Comporta) and grey (São Jacinto) dots. Taxonomic classification follows Schwarzott et al. (2001). Bootstrap values are based on 1,000 replicates, percentage values are shown

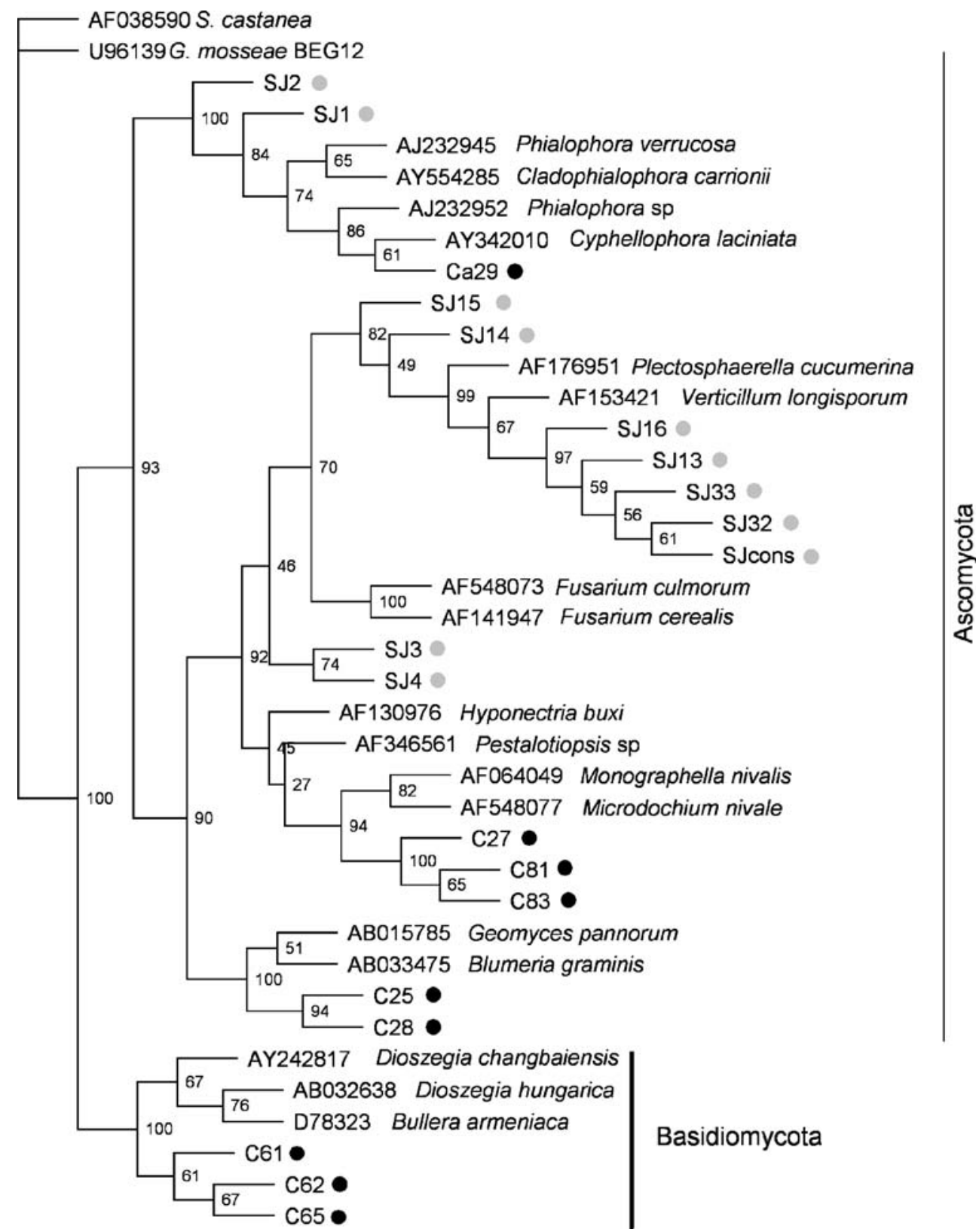

(four of them from spores) grouped within the cluster GlGrAb (Schwarzott et al. 2001). Half of the remaining clones clustered with the isolate G W3347, which was an outlier in the phylogenetic analysis of the genus Glomus by Schwarzott et al. (2001), and could be part of the proposed group GlGrAc.

As in other molecular studies of AMF in planta, most of the sequences obtained in this study did not match previously described AMF species suggesting a higher natural AMF diversity than acknowledged from culture collections. However, the true meaning of this genetic variation is still unknown (Munkvold et al. 2004; Sanders 2004). Nevertheless, the highest diversity of AMF sequences was found in the samples from São Jacinto. Since the vegetation in this site has a much better conservation status, these data would agree with other studies that suggest a positive correlation between AMF diversity and ecosystem functioning (Johnson et al. 2004; Kowalchuk et al. 2002; Newsham et al. 1995).

Cosmopolitan Glomus spp were found in A. arenaria as revealed by the similarity of some clones and AMF sequences obtained from other plant species and ecosystems (Öpik et al. 2003; Vandenkoornhuyse et al. 2003; Wirsel 2004). Only one clone showed homology with sequences from a study of AMF in A. arenaria in The Netherlands (Kowalchuk et al. 2002). Two subspecies of $A$. arenaria grow in Europe, the subspecies arenaria grows in the northern coast and ssp. arundinacea appears in areas 
under a Mediterranean climate. Our data question whether these two subspecies preferentially associate to different AMF species, or whether the differences found in the AMF communities are a consequence of the distance between the sites studied by Kowalchuk et al. (2002) and those studied in this work. Biogeographical variation is likely to happen, as it was also found between the root samples from Comporta and São Jacinto, but genetic specificity in the symbiosis cannot be excluded.

DNA sequencing proved to be useful to find the Glomus species identified from spores inside $A$. arenaria roots, a result that cannot be achieved by morphological studies. However, none of the clones obtain from $A$. arenaria roots showed similarity with the sequences from $S$. persica spores, showing that molecular methods can also be biased. This species is commonly associated with $A$. arenaria as it has been previously reported from coastal dunes in Poland (Blaszkowski and Tadych 1997). This AMF species must be colonising $A$. arenaria roots because this plant grows in monocultures and $S$. persica spores were very abundant in the soil samples. However, if the levels of root colonization by $S$. persica are much lower than those of Glomus spp. our molecular design might have failed detecting the presence of $S$. persica inside the roots because of the preferential amplification of more abundant sequences during the PCR.

The diversity of non-AMF sequences was higher in the samples from Comporta than in those from São Jacinto. Although the plants in Comporta do not look as healthy as those in São Jacinto, the higher fungal diversity did not result in more plant pathogenic fungi associated with the roots of plants from Comporta. Three of the clones from Comporta represent Basidiomycota fungi with a high similarity with the yeasts Dioszegia hungarica and Bullera armenica. These species are commonly associated with mycorrhizal roots and AMF spores (Renker et al. 2004), but the putative interactions between AMF and yeasts is yet unknown. The remaining non-AMF clones were from ascomycetes closely related to plant and human pathogens or saprophytic fungi. From those Ascomycota fungi, only Fusarium culmorum and Microdochium sp were previously reported from the roots of $A$. arenaria (de Rooij-van der Goes 1995; Kowalchuk et al. 1997).

Basic knowledge of the fungal diversity associated with A. arenaria may be useful for the conservation and restoration of coastal sand dunes. This study has detected, using cloning and partial sequencing of the SSU rDNA, fungal species newly associated with the sand dune plant $A$. arenaria. Although the subspecies arundinacea occurs in the highly threatened Mediterranean coastal dunes, the information on the AMF diversity associated with this plant is still scarce. Furthermore, to our knowledge, this is the first molecular study of AMF associated with $A$. arenaria spp. arundinacea. In short, most of the clones belonged to the genus Glomus sensu lato, the larger clade within the Glomeromycota fungi. Members of the families Diversisporaceae and Gigasporaceae were detected in the ecosystem that was better preserved, showing a higher systematic diversity of mutualistic fungi in the healthy dune system than in the disturbed dunes.

Acknowledgements We thank Dr. Chris Walker for the determination of AMF species and his comments on the manuscript, and Gilberto Silva, João Crisóstomo and Dr. Mann for their help in the sampling. This work was funded by the EU project EcoTrain (HPRNCT-2002-00210)

\section{References}

Allen MF (1996) The ecology of arbuscular mycorrhizas: a look back into the 20th century and a peek into the 21st. Mycol Res 100:769-782

Altschul SF, Madden TL, Schaffer AA, Zhang J, Zhang Z, Miller W, Lipman DJ (1997) Gapped BLAST and PSI-BLAST: a new generation of protein database search programs. Nucleic Acids Res 25:3389-3402

Azcón-Aguilar C, Barea JM (1996) Arbuscular mycorrhizas and biological control of soil-borne plant pathogens - an overview of the mechanisms involved. Mycorrhiza 6:457-464

Blaszkowski J (1994) Arbuscular fungi and Mycorrhizae (Glomales) of the Hel Peninsula, Poland. Mycorrhiza 5:71-88

Blaszkowski J, Tadych M (1997) Scutellospora persica (Glomales, Zygomycetes), an arbuscular mycorrhizal fungus new to the mycota of Poland. Mycotaxon 65:379-390

Blaszkowski J, Tadych M, Madej T (2001) Glomus arenarium, a new species in Glomales (Zygomycetes). Acta Soc Bot Pol 70:97-101

Carter RWG (1988) Coastal dunes. In: RWG Carter (ed) Coastal environments: an introduction to the physical, ecological and cultural systems of coastlines. Academic, London, pp301-333

de la Peña E, Rodriguez-Echeverria S, van der Putten WH, Freitas H, Moens M (2006) Mycorrhizal fungi control migratory endoparasitic nematodes in Ammophila arenaria. New Phytol 169: 829-840

de Rooij-van der Goes PCEM (1995) The role of plant-parasitic nematodes and soil-borne fungi in the decline of Ammophila arenaria (L) Link. New Phytol 129:661-669

De Souza FA, Leeflang P, Kowalchuk GA, van Veen JA, Smit E (2004) PCR-denaturing gradient gel electrophoresis profiling of the inter- and intraspecies 18S rDNA gene sequence heterogeneity as an accurate and sensitive method to assess species diversity of arbuscular mycorrhizal fungi of the genus Gigaspora. Appl Environ Microbiol 70:1413-1424

Douhan GW, Petersen C, Bledsoe CS, Rizzo DM (2005) Contrasting root associated fungi of three common oak-woodland plant species based on molecular identification: host specificity or non-specific amplification? Mycorrhiza 15:365-372

Felsenstein J (1993). PHYLIP 3.5. Distributed by the author

Ferrol N, Calvente R, Cano C, Barea JM, Azcon-Aguilar C (2004) Analysing arbuscular mycorrhizal fungal diversity in shrubassociated resource islands from a desertification-threatened semiarid Mediterranean ecosystem. Appl Soil Ecol 25:123-133

Giovannetti M (1985) Seasonal variation of vesicular-arbuscular mycorrhizas and endogonaceous spores in a maritime sand dune. Trans Br Mycol Soc 84:679-684

Giovannetti M, Nicolson TH (1983) Vesicular-arbuscular mycorrhizas in Italian sand dunes. Trans Br Mycol Soc 80:552-557 
Greig-Smith P (1961) Data on pattern within plant communities. II. Ammophila arenaria (L.) Link. J Ecol 49:703-708

Hall TA (1999) BioEdit: a user-friendly biological sequence alignment editor and analysis program for Windows 95/98/NT. Nucleic Acids Symp Ser 41:95-98

Helgason T, Daniell TJ, Husband R, Fitter AH, Young JPW (1998) Ploughing up the woodwide web? Nature 394:431

Huiskes AHL (1979) Biological flora of the British Isles. J Ecol 67:363-382

Husband R, Herre EA, Turner SL, Gallery R, Young PW (2002) Molecular diversity of arbuscular mycorrhizal fungi and patterns of host association over time and space in a tropical forest. Mol Ecol 11:2669-2678

Johnson D, Vandenkoornhuyse PJ, Leake JR, Gilbert L, Booth RE, Grime JP, Young JPW, Read DJ (2004) Plant communities affect arbuscular mycorrhizal fungal diversity and community composition in grassland microcosms. New Phytol 161:503-515

Kimura M (1980) A simple model for estimating evolutionary rates of base substitutions through comparative studies of nucleotide sequences. J Mol Evol 16:111-120

Koske RE (1975) Endogone species in Australian sand dunes. Can J Bot 53:668-672

Koske RE, Polson WR (1984) Are VA mycorrhizae required for sand dune stabilization? Bioscience 34:420-424

Kowalchuk GA, Gerards S, Woldendorp JW (1997) Detection and characterization of fungal infections of Ammophila arenaria (marram grass) roots by denaturing gradient gel electrophoresis of specifically amplified 18S rDNA. Appl Environ Microbiol 63:3858-3865

Kowalchuk GA, De Souza FA, Van Veen JA (2002) Community analysis of arbuscular mycorrhizal fungi associated with Ammophila arenaria in Dutch coastal sand dunes. Mol Ecol 11:571-581

Kramadibrata K, Walker C, Schwarzott D, Schüßler A (2000) A new species of Scutellospora with a coiled germination shield. Ann Bot 86:21-27

Ma WK, Siciliano SD, Germida JJ (2005) A PCR-DGGE method for detecting arbuscular mycorrhizal fungi in cultivated soils. Soil Biol Biochem 37:1589-1597

Maremmani A, Bedini S, Matosevic I, Tomei PE, Giovannetti M (2003) Type of mycorrhizal associations in two coastal nature reserves of the Mediterranean basin. Mycorrhiza 13:33-40

Munkvold L, Kjøller R, Vestberg M, Rosendahl S, Jakobsen I (2004) High functional diversity within species of arbuscular mycorrhizal fungi. New Phytol 164:357-364

Newsham KK, Fitter AH, Watkinson AR (1995) Multi-functionality and biodiversity in arbuscular mycorrhizas. Trends Ecol Evol $10: 407-411$
Öpik M, Moora M, Liira J, Köljalg U, Zobel M, Sen R (2003) Divergent arbuscular mycorrhizal fungal communities colonize roots of Pulsatilla spp. in boreal Scots pine forest and grassland soils. New Phytol 160:581-593

Page RDM (2001) TREEVIEW 1.6.6. Distributed by the author

Redecker D, Morton JB, Bruns TD (2000) Molecular phylogeny of the arbuscular mycorrhizal fungi Glomus sinuosum and Sclerocystis coremioides. Mycologia 92:282-285

Renker C, Blanke V, Börstler B, Heinrichs J, Buscot F (2004) Diversity of Cryptococcus and Dioszegia yeasts Basidiomycota inhabiting arbuscular mycorrhizal roots or spores. FEMS Yeast Res 4:597-603

Rosendahl S, Stukenbrock EH (2004) Community structure of arbuscular mycorrhizal fungi in undisturbed vegetation revealed by analyses of LSU rDNA sequences. Mol Ecol 13:3179-3186

Sanders IR (2004) Plant and arbuscular mycorrhizal fungal diversity - are we looking at the relevant levels of diversity and are we using the right techniques? New Phytol 164:415-418

Schüßler A, Schwarzott D, Walker C (2001) A new fungal phylum, the Glomeromycota: phylogeny and evolution. Mycol Res 105:1413-1421

Schwarzott D, Walker C, Schüßler A (2001) Glomus, the largest genus of the arbuscular mycorrhizal fungi (Glomales), is nonmonophyletic. Mol Phylogenet Evol 21:190-197

Simon L, Lalonde M, Bruns TD (1992) Specific amplification of $18 \mathrm{~S}$ fungal ribosomal genes from vesicular-arbuscular mycorrhizal fungal communities. Appl Environ Microbiol 58:291-295

Tutin GT, Heywood VH, Burges NA, Moore DM, Valentine DH, Walters SM, Webb DA (1980) Flora Europaea. Cambridge University Press, Cambridge

Vandenkoornhuyse P, Ridgway KP, Watson IJ, Fitter AH, Young JPW (2003) Co-existing grass species have distinctive arbuscular mycorrhizal communities. Mol Ecol 12:3085-3095

van Tuinen D, Jacquot E, Zhao B, Gollote A, Gianinazzi-Pearson V (1998) Characterization of root colonization profiles by a microcosm community of arbuscular mycorrhizal fungi using 25S rDNA-targeted nested PCR. Mol Ecol 7:879-887

Walker C (2005) A simple blue staining technique for arbuscular mycorrhizal and other root-inhabiting fungi. Inoculum 56:68-69

White TJ, Bruns T, Lee S, Taylor J (1990) Amplification and direct sequencing of fungal ribosomal RNA genes for phylogenetics. In: Innis MA, Gelfand DH, Sminski JJ, White TJ (eds) PCR protocols: a guide to methods and applications. Academic, San Diego, pp315-322

Wirsel SGR (2004) Homogenous stands of a wetland grass harbour diverse consortia of arbuscular mycorrhizal fungi. FEMS Microb Ecol 48:129-138 